\title{
Implementasi Pembelajaran berbasis Pemanfaatan Lingkungan Sekitar untuk Meningkatkan Aktivitas Belajar IPA SD
}

\author{
Atin Kurniawati ${ }^{1}$, Annissa Mawardini ${ }^{2}$ \\ Fakultas Keguruan Ilmu dan Pendidikan, Universitas Djuanda \\ Atinkurniawati.a10@gmail.com
}

Diterima 30 Agustus 2017; Direview 24 September 2017; Diterima 20 Oktober 2017

Diterbitkan online 21 Desember 2017

\begin{abstract}
This study aims to (1) maxsimal real learning science in elementary scool with utilization enviroment. (2) to concept science learning in elementary school as meaningful and qualified via utilization enviroment. (3) to made inovation of science learning in elementary school with utilization enviroment as can activated students. Methode used in this study is experiment with used design pretest-posttest control group. Data subject used are student class V Amalia of integrated islamic elementary school as count 41 student (2 class) with collected data instrument as pretest, posttest and observation sheet. Technic of data analist used descriptif analist, prerequisite eximanated as normality test. Kolmogrov Smirnov models with SPSS 17.0 for windows program., and homogenity test with Levene on SPSS 17.0 for windows and also hipotesis testing as one way ANOVA test that is on SPSS program.
\end{abstract}

Keywords: learning based on utilization enviroment, activitty of study, elementary school science.

\begin{abstract}
Abstrak
Penelitian ini bertujuan (1) untuk memaksimalkan pembelajaran ril IPA SD dengan pemanfaatan lingkungan sekitar (2) untuk mengkonsep pembelajaran IPA SD yang bemakna dan berkualitas lewat pemanfaatan lingkungan sekitar (3) untuk membuat inovasi pembelajaran IPA SD dengan pemanfaatan lingkungan sekitar yang dapat mengaktivkan siswa. Metode yang digunakan dalam penelitian ini adalah eksperimen serta menggunakan desain pretest-posttest control group. Subjek data yang digunakan adalah siswa kelas V SD SD IT Amalia sejumlah 41 siswa (2 kelas) dengan instrumen pengumpulan data berupa soal pretest, soal posttest dan lembar observasi. Teknik analisis data menggunakan analisis deskriptif, pengujian prasyarat berupa uji normalitas model Kolmogrov Smirnov dengan program SPSS 17.0 for windows. dan uji homogenitas dengan menggunakan model homogenitas Levene dalam program SPSS 17.0 for windows serta pengujian hipotesis berupa one way ANOVA test yang terdapat pada program SPSS.
\end{abstract}

Kata kunci: pembelajaran berbasis pemanfaatan lingkungan sekitar, aktivitas belajar, IPA SD.

\section{PENDAHULUAN}

Pembelajaran IPA dalam segala segmen tingkat jenjang pendidikan mulai dari dasar hingga perguruan tinggi tidak akan lepas dari dimensi fakta, prinsip, konsep dan proses. Pembelajaran tidak hanya berupa sebuah transfer ilmu, melainkan ada sisi lain bagaimana memahamkan sesuatu pada peserta didik terhadap suatu materi hingga ia pun dapat mengaplikasikannya. IPA akan lebih terasa menyenangkan manakala peserta didik dihadapkan pada situasi kondisi ril, yakni diantaranya dengan membelajarkan mereka lewat lingkungan/alam. Pembelajaran seperti ini tentunya melibatkan proses peserta didik secara langsung didalamnya. Sehingga ia bisa merasakan sendiri atau melakukan sendiri. Pembelajaran dengan konteks ril secara tidak langsung melibatkan peserta didik secara 
aktif. Karena pada pembelajaran ini siswa sendiri terjun dan terlibat secara langsung.

Sesuai dengan tujuan pendidikan dalam undang - undang UU No 20 Tahun 2003 tentang sistem pendidikan nasional disebutkan bahwa tujuan pendidika nasional adalah mengembangkan kemampuan dan membentuk watak serta peradaban bangsa yang bertujuan untuk mengembangkan potensi yang dimiliki peserta didik agar menjadi manusia yang berkualitas dengan ciri-ciri beriman dan bertaqwa kepada Tuhan Yang Maha Esa, berakhlak mulia, sehat beriman, cakap, kreatif mandiri, dan menjadi warga Negara yang demokratis serta tanggung jawab.

Hal tersebut dimaksudkan untuk membentuk para penerus bangsa yang kreatif dan mampu mengembangkan dirinya menjadi manusia berkualitas. Proses pendidikan yang baik adalah pendidik harus mengetahui, memperhatikan dan mengembangkan minat belajar siswa karena minat sangat penting dalam keberhasilan suatu kegiatan belajar mengajar. Pengemasan pembelajaran yang menarik dapat mempanfaatkan alam atau lingkungan sebagai sarananya. Pun ini juga dapat menjadi solusi ketika di dalam pembelajaran terkendala akan adanya keterbatasan peralatan.

Pengemasan konsep pembelajaran dengan pemanfaatan lingkungan sejalan dengan 4 pilar pendidikan yakni (1) learning to know (belajar untuk mengetahui), (2) learning to do (belajar untuk mengerjakan sesuatu), (3) learning to be (belajar untuk menjadi jati dirinya), (4)learning live together (belajar untuk bekerjasama).

Jalannya proses pendidikan dalam lingkup disekolah dasar juga dipengaruhi oleh prasarana pendidikan terutama untuk keberlangsungan kegiatan pembelajaran. Beberapa sekolah sering memanfaatkan lingkungan yang ada disekitarnya sebagai alternatif pelaksanaan kegiatan belajar. Diantranya adalah yang dilakukan oleh SD Amalia kelas V yang terdiri dari 5 paralel dengan masing-masing kelas sejumlah 20 dan 21 siswa per kelasnya. Berdasarkan observasi yang telah dilakukan dan lembar angket yang telah dibagikan, beberpa guru sekolah tersebut sudah pernah melaksnakan pembelajaran dengan memanfaatkan lingkungan yang ada disekitarnya. Alasan sebagian besar yang dikemukakan karena siswa merasa lebih senang karena belajar di tempat yang terbuka, berkaitan langsung dengan alam sekitar serta jangkauan biaya yang lebih murah. Disamping itu konsep pembelajaran seperti ini juga mengajak siswa untuk belajar pada kondisi ril sehingga siswa dapat menerapakan konsep-konsep yang teori yang telah didapatkan. Disisi lain siswa diajarkan untuk mencintai dan peduli pada lingkungan, terutama lingkungan sekitar mereka. Disamping itu ketika pembelajaran dilakukan di luar dalam artian lingkungan sekitar maka itu juga menuntut siswa untuk lebih aktif dalam kegiatan pembelajaran. 
Beranjak dari hal tersebut maka perlu adanya penelitian "Implementasi pembelajaran dengan memanfaatkan lingkungan sekitar untuk meningkatkan aktifitas belajar IPA SD”, dengan mengambil sampel 2 kelas. Adapun tujuan penelitian:

1. Untuk memaksimalkan pembelajaran ril IPA SD dengan pemanfaatan lingkungan sekitar.

2. Untuk mengkonsep pembelajaran IPA SD yang bemakna dan berkualitas lewat pemanfaatan lingkungan sekitar.

3. Untuk membuat inovasi pembelajaran IPA SD dengan pemanfaatan lingkungan sekitar yang dapat mengaktifkan siswa.

Manfaat dari penelitian yaitu:

1. Membuat konsep pembelajaran IPA SD yang bemakna dan berkualitas lewat pemanfaatan lingkungan sekitar yang dapat meningkatkan pengembangan pembelajaran di lingkup sekolah dasar.

2. Membuat inovasi pembelajaran ril mata pelajaran IPA SD dengan pemanfaatan lingkungan sekitar yang dapat mengaktifkan siswa yang dapat digunakan dalam kemajuan pendidikan terutama merangsang kreativitas peneliti dalam pengemasan pembelajaran yang mengintegrasikan alam dan lingkungan dalam pembelajaran.

\section{METODE PENELITIAN}

Jenis penelitian ini adalah penelitian eksperimen. Dengan menggunakan desain pretest-posttest control group. Yakni menggunakan dua kelas, kontrol dan eksperimen. Sebelum perlakuan/treatmen masing masing kelas diberikan tes yakni untuk mengetahui kemampuan awal siswa. Selanjutnya masing -masing kelas tersebut diberikan treatmen/perlakuan lantas diobservsi untuk mengetahui sejauhmana hasilnya. Dilanjutkan dengan pemberian tes di akhir setelah treatmen dilaksankan. Hal tersebut digunakan sebagai bahan untuk mengukur pengaruh peningkatan keaktivan siswa dari treatmen yang telah diberikan. Penelitian ini dilaksanakan di SD SD IT Amalia Kabupaten Bogor. Jumlah dari subjek penelitian ini adalah 41 siswa (2 kelas). Teknik pengambilan sampel menggunakan non probability sampling dengan jenis teknik sampling jenuh, yaitu menggunakan seluruh anggota populasi sebagai sampel penelitian. Variabel-variabel dalam penelitian ini ada dua, yaitu: (1) variabel bebas yaitu pembelajaran berbasis lingkungan, variabel terikat yaitu aktivitas belajar siswa. Metode yang digunakan untuk mengumpulkan data adalah wawancara, observasi, tes, dokumentasi dan kuesioner. Teknik analisis data yang digunakan adalah uji normalitas liliefors untuk mengetahui data berdistribusi normal dan teknik analisis uji-t untuk menguji hipotesis penelitian.

Data dalam penelitian yaitu berupa hasil soal pretest, hasil soal posttest, hasil data observasi dan juga isian angket dari siswa. Hasil soal pretest diperoleh sebelum treatmen proses pembelajaran dan hasil pengerjaan soal 
posttest diperoleh setelah treatmen proses pembelajaran. Adapun hasil observasi diperoleh pada saat siswa melakukan aktivitas saat proses pembelajaran serta pada awal pra awal peneltian. Data isian angket siswa diperoleh setelah proses pembelajaran selesai.

Data dalam penelitian ini diperoleh dengan memberikan soal pretest, soal posttest, lembar observasi dan juga angket. Pemberian tes dilakukan dua kali. Soal pretest diberikan pada saat awal sebelum pemberian perlakuan/ treatment, yaitu dua minggu sebelum pembelajaran baik di kelas kontrol maupun eksperimen. Tujuannya yaitu untuk mengetahui kemampuan awal siswa. Dilanjutkan dengan memberikan perlakuan pada masing-masing kelas kontrol maupun eksperimen. Untuk kelas kontrol diberi perlakuan berupa pembelajaran tetap dilakukan di dalam kelas. Sedangkan untuk kelas eksperimen diberi perlakuan dengan melakukan pembelajaran dilakukan di luar kelas yaitu di lingkungan sekitar sekolah. Selama pemberian perlakuan siswa dinilai dengan menggunakan lembar observasi. Siswa diamati terkait dengan keaktivannya selama pembelajaran. Pada saat pengamatan dilakukan dengan tidak mengganggu keberlangsungan pembelajaran. Tahap selanjutnya memberikan posttest pada kelas kontrol maupun eksperimen untuk mengetahui dan mengukur sejauhmana aktivitas belajar siswa setelah diberikan perlakuan. Terakhir siswa diberikan berikan angket. Angket ini digunakan untuk mengetahui pendapat pribadi siswa setelah diberikan pembelajaran terkait dengan aktivitasnya.

Untuk menganalisis data yang diperoleh pada penelitian, dilakukan melalui analisis data deskriptif dan analisis uji hipotesis.

1) Analisis deskriptif

Deskrepsi data dilakukan dengan analisis deskreptif terhadap variabel-variabel penelitian. Data yang diperoleh dari hasil pretest maupun posttest yang berupa nilai tentang aktivitas siswa dibandingkan hasilnya. Untuk mengetahui adanya peningkatan aktivitas belajar siswa dapat diketahui dengan melihat peningkatan nilai posttest dibanding dengan pretest. Pengujian prasyarat

a. Uji Normalitas Data Sampel

Uji normalitas data sampel digunakan untuk mengetahui apakah dari masingmasing variabel berdistribusi normal atau tidak. Uji normaliats dilakukan baik pada kelas kontrol maupun eksperimen. Pengujian normaliatas data menggunakan model Kolmogrov Smirnov dengan program SPSS 17.0 for windows. Hipotesis yang diajuakan untuk pengujian ini adalah:

Ho : Data berdistribusi normal.

Ha : Data tidak berdistribusi normal.

Kriteria pengujian yang digunakan untuk mengukur normalitas populasi dalam penelitian ini adalah menerima 
Ho apabila nilai Asymp. Sig. (2-tailed)

$>\alpha$ yang ditetapkan yaitu 0,05 .

b) Uji Homogenitas Variansi

Uji homogenitas variansi dilakukan untuk mengetahui apakah subjek penelitian berasal dari populasi yang homogen atau tidak. Uji homogenitas ini dilakukan terhadap kelas kontrol maupun eksperimen.

Perhitungan uji homogenitas dilakukan dengan menggunakan model homogenitas Levene dalam program SPSS 17.0 for windows. Hipotesis yang diajukan untuk mengukur homogenitas ini adalah sebagai berikut:

Ho : Varian data adalah sama (homogen).

Ha : Varian data tidak sama (heterogen).

Kriteria yang digunakan untuk menentukan homogenitas varian adalah menerima Ho apabila Asymp. Sig. (2tailed) $>\alpha$ yang ditetapkan yaitu 0,05 .

2) Pengujian hipotesis

Adapun hipotesis yang diajukan yaitu:

Ho :Pembelajaran Berbasis Pemanfaatan Lingkungan Sekitar Dapat

Meningkatkan Aktivitas Belajar IPA SD.

Ha :Pembelajaran Berbasis Pemanfaatan Lingkungan Sekitar Tidak Dapatc Meningkatkan Aktivitas Belajar IPASD.

Statistik uji yang digunakan adalh one way ANOVA test yang terdapat pada program SPSS. Kriteria keputusannya yaitu Ho diterima jika p-value (sig) $>\alpha$ dengan $\alpha=0,05$.

\section{HASIL DAN PEMBAHASAN}

\section{a. Pemvalidasian Instrumen}

Pemvalidasian instrumen penelitian yaitu kepada expert judgment. Berdasarkan pemvalidasian instrumen yang telah dilakukan semua item instrumen dinyatakan valid berdasarkan perhitungan menurut (Aiken, 1980:956).

\section{b. Pengujian Prasyarat}

Pengujian normalitas untuk kelas eksperimen (VC) meghasilkan nilai Asymp. Sig. (2-tailed) sebesar 0,200. Data tersebu menunjukan bahwa kelas eksperimen (VC) berdistribusi normal dan layak untuk digunkan dalam penelitian.

Pengujian normalitas untuk kelas eksperimen (VC) meghasilkan nilai Asymp. Sig. (2-tailed) sebesar 0,112. Data tersebu menunjukan bahwa kelas eksperimen (VC) berdistribusi normal dan layak untuk digunakan dalam penelitian.

Pengujian homogenitas meghasilkan nilai sig sebesar 0,093. Karena sig $(0,093)>\alpha$ $(0,05)$, maka Ho diterima. Dari hasi tersebut menunjukan bahwa subjek data berasal dari populasi yang homogen (varian data adalah sama).

\section{c. Analisis DIskriptif}

\section{1) Kelas VC}

Sebelum pelaksanaan pembelajaran berbsis lingkungan siswa diberikan soal pre test 
untuk mengukur kemampuan awal. Berdasarkan data yang dipeoleh skor rata-rata pre test untuk kelas VC 56,14. Pada akhir pembelajaran berbasis lingkungan siswa diberikan soal post test dengan maksud untuk mengetahui bagaimana aktivitas siswa setelah diberikan pembelajaran berbasis lingkungan. Berdasarkan data yang diperoleh skor ratarata post test kelas $\mathrm{VC} 63,89$. Hal tersebut mengimplikasikan bahwa pembelajaran berbasis lingkungan meningkatkan aktivitas siswa sebesar $7,75 \%$.

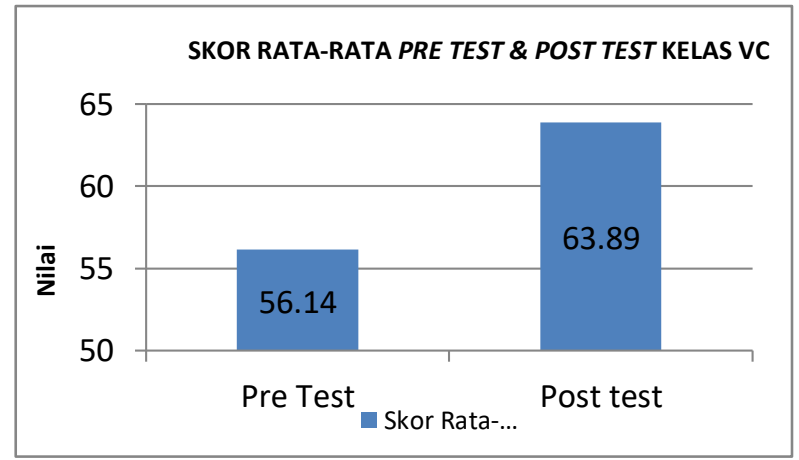

Grafik 1. Skor Rata-rata Pre Test dan Post

\section{Test Kelas VC}

Berdasarkan soal pre test yang mengukur aktivitas siswa, siswa sudah bagus untuk aspek (1) menjelaskan, (2) mendefinisikan, (3) menjelaskan, (4)membandingkan, mempraktekan, (8) melaksnakan, mengklasifikasikan, (10) menyelesaikan dengan skor > 3 dan masih kurang untuk (5) mengklasifikasikan, (6) menyusun dengan skor $<3$.

Berdasarkan soal post test yang mengukur aktivitas siswa, siswa sudah bagus untuk aspek (1) menjelaskan (2)mengidentifikasi (3) menjelaskan (4) membandingkan menjelaskan (6) menyusun (7) mempraktekan
(Melaksnakan dengan skor > 3 dan masih kurang untuk (9) Mengklasifikasikan, (10) menyelesaikan dengan skor $<3$.

Seusai pelaksanaan pembelajaran berbasis lingkungan selesai, siswa diberikan angket peserta didik. Angket peserta didik diberikan untuk mengetaui pendapat atau apa yang sudah dirasakan oleh siswa dengan pembelajaran berbasis lingkungan. Dari angket yang sudah dibagikan diperoleh skor rata-rata 3,45 dengan predikat baik. Dengan rincian dari 10 orang siswa 6 orang siswa perolehan sor rata-rata dalam predikat sabgat bai dan 4 orang siswa dalam kategori baik. Angket Peserta didik ditinjau dari per bidang aspek dari12 aspek, kesemuanya mendapatkan skor rata-rata dalam predikat sangat baik. Pada saaat pelaksanaan pengisian angket hanya ada 10 orang siswa, dikarenakan pada saat itu banyak siswa yang tidak hadir.

Untuk menilai kinerja siswa pada saat pelaksanaan pembelajaran berbasis lingkungan sekitar pada pertemuan 1, maka dilakukan penilaian performance. Penilaian performance merupakan penilaian kinerja siswa pada saat pembelajaran dengan dihadapkan pada kondisi ril. Berdasarkan penilaian penilaian performance yang telah dilakukan diperoleh skor rata rata 3,37 dalam kategori baik. Dari 21 siswa terdapat 10 siswa dengan kriteria cukup baik dan 11 siswa dalam kategori baik. Dari 11 aspek, performance yang dinilai, siswa sudah dalam kateori sangat baik untuk menyimpulkan. Pengamatan saat eksperimen keterampilan 
mengobservasi, mengidentifikasi dan mengontrol variabel dan mengomunikasikan. Siswa dalam penilaian performance dalam kateori baik untuk aspek pengamatan saat eksperimen keterampilan mengobservasi, mengidentifikasi dan mengontrol variabel dan mengomunikasikan. Untuk penilaian performance siswa masih dalam kateori cukup baik pada aspek mengklasifikasikan memprediksi, menyusun hipotesis, melakukan eksperimen, mengukur dan menggunakan angka, menginterpretasikan data menginterpretasikan data.

Untuk penilaian penilaian performance yang telah dilakukan pada pertemuan 2 diperoleh skor rata rata 4,29 dalam kategori sangat baik. Dari 21 siswa, kesemuanya dalam kategori sangat baik. Dari 11 aspek, performance yang dinilai, siswa sudah dalam kateori sangat baik untuk Pengamatan saat eksperimen keterampilan, mengobservasi, mengklasifikasikan, memprediksi, menyusun hipotesis, mengidentifikasi dan mengontrol variabel, melakukan eksperimen, mengukur dan menggunakan angka, menginterpretasikan data, menganalisis data, mengomunikasikan dan menyimpulkan. Untuk penilaian performance siswa dalam kategori baik pada aspek mengklasifikasikan.

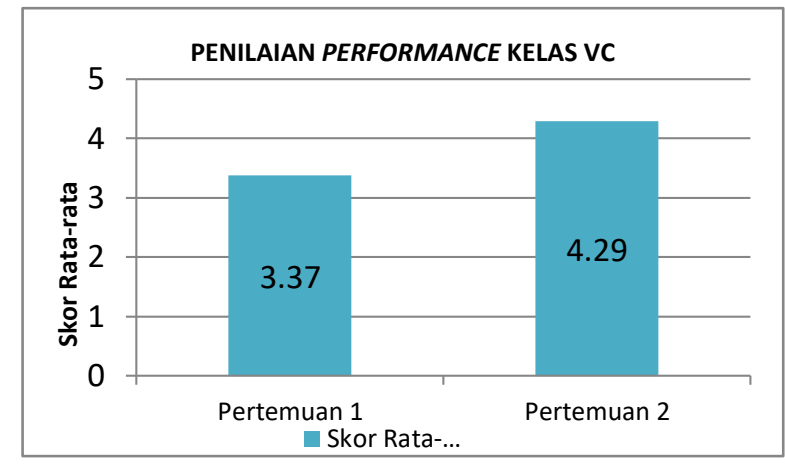

\section{Grafik 2. Penilaian Performance Kelas VC}

\section{1) Kelas VE}

Pembelajaran berbasis pemanfaatan lingkungan setelah dilakukan treatmen dengan demonstrasi terhadap kelas VE kurang memberikan dampak terhadap aktivitas siswa IPA untuk pokok bahasan. " Kegiatan Manusia Yang Mempengaruhi Keseimbangan LingkunganSekitar/Alam, Kerusakan Lingkungan dan Perubahan Alam”. Dapat dilihat dari nilai pre test dan post test yang diberikan. Secara keseluruhan nilai rata-rata untuk pre test 67,25 dan nilai post test 57,60 dengan penurunan sebesar $9,65 \%$.

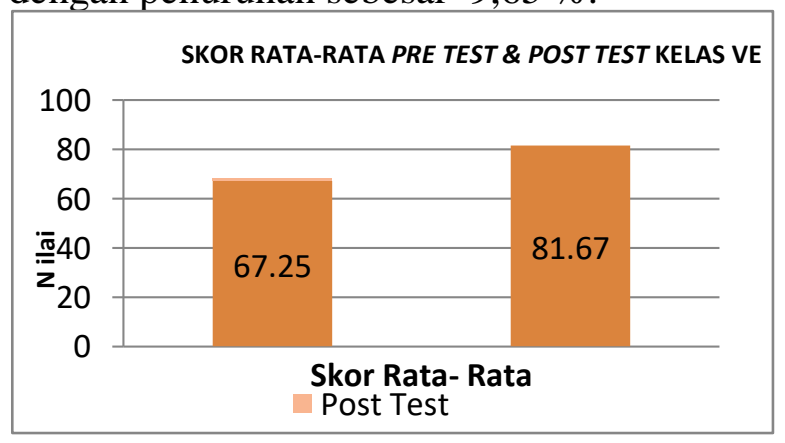

\section{Grafik 3. Skor Rata-rata Pre Test dan Post Test}

Pada pre test siswa yang sudah mencapai nilai KKM ( $\geq 70) 9$ orang $(52,94 \%$ ), dan yang belum mencapai KKM $(\leq 70) 8$ orang $(47,06 \%)$ dari total siswa yang mengikuti pre test 17 siswa. Pada post test siswa yang sudah mencapai nilai KKM ( $\geq 70) 4$ Orang $(26,67$ $\%)$, dan yang belum mencapai 11 Orang $(73,33 \%)$ dari total siswa yang mengikuti pre test 15 siswa.

Soal pre test yang mengukur aktivitas siswa, siswa sudah bagus untuk aspek (1) menjelaskan (2) mendefinisikan menjelaskan (4) membandingkan 
mengklasifikasikan (7) mempraktekan (8) melaksnaka, dan (10) menyelesaikan dengan skor > 3 dan masih kurang untuk (6) menyusun, (9) mengklasifikasikan dengan skor $<3$.

Berdasarkan soal post test yang mengukur aktivitas siswa, siswa sudah sangat bagus untuk aspek (1) menjelaskan, mendefinisikan, (5) mengklasifikasikan (7) mempraktekan, baik untuk aspek melaksanakan, cukup baik untuk aspek (3) menjelaskan

(6) menyusun menyelesaikan dan masih kurang baik untuk aspek (4) membandingkan mengklasifikasikan.

Pada saat pelaksanaan pembelajaran berbasis lingkungan untuk mengukur aktivitas siswa secara objektif maka dilakukan penilaian antar teman. Penilaian antar teman ini dilakukan untuk mengetahui aktivitas siswa selama proses pembelajaran berdasarkan pendapat temannya. Secara keseluruhan rata-rata penilaian antar teman menujukan bahwa aktivitas belajar siswa dala kategori baik dengan skor 4,88. Dengan rincian 7 siswa aktivitas siswanya dalam kategori sangat baik, 7 siswa dalam kategori baik, 1 siswa dalam kateori kurang baik dan 1 siswa dalam kategori tidak baik.

Untuk penilaian antar teman ditinjau dari per bidang aspek dari 8 aspek rata-rata skor perolehan dalam kategori sangat baik untuk aspek (6) melakukan percobaan/demonstrasi/ praktikum berupa pembuatan prototipe, dan aspek (8) merasa senang saat kegiatan belajar mengajar berbasis lingkungan. Untuk rata-rata skor perolehan dalam kategori sangat baik untuk aspek (1) melakuakan pembacaan pengukuran percobaan/ demonstrasi/ praktikum. (2) mampu menyatakan pendapat pada saat pembelajaran/ percobaan/ demonstrasi/ praktiku. (3) menyimak pada saat berlangsungnya proses belajar mengajar, (4) membuat laporan, (5) grafik/ diagram, (7) menganalisis data percobaan/ demonstrasi/ praktikum.

Dari data tersebut dapat diimplikasikan bahwa pada kelas kontrol siswa aktif. Namun jika dibandingkan dengan kelas eksperimen yang diberi perlakuan pembelajaran berbasis lingkungan sekitar dilihat dari aktivitas siswa maka kelas eksperimen (VC) lebih aktif , yakni dapat dilihat dari perolehan skor rata penilaian antar teman 4,22 (SB) > penilaian antar teman kelas kontrol (VE) 3,87 (B).

Pada saat pelaksanaan pembelajaran berbasis lingkungan untuk mengukur aktivitas siswa secara objektif maka dilakukan penilaian antar teman. Penilaian antar teman ini dilakukan untuk mengetahui aktivitas siswa selama proses pembelajaran berdasarkan pendapat temannya. Secara keseluruhan rata-rata penilaian antar teman menujukan bahwa aktivitas belajar siswa dala kategori baik dengan skor 4,88. Dengan rincian 7 siswa aktivitas siswanya dalam kategori sangat baik, 7 siswa dalam kategori baik, 1 siswa dalam kateori kurang baik dan 1 siswa dalam kategori tidak baik. 
Untuk penilaian antar teman ditinjau dari per bidang aspek dari 8 aspek rata-rata skor perolehan dalam kategori sangat baik untuk aspek (6) melakukan percobaan/demonstrasi/ praktikum berupa pembuatan prototipe, dan aspek (8) merasa senang saat kegiatan belajar mengajar berbasis lingkungan. Untuk rata-rata skor perolehan dalam kategori sangat baik untuk aspek (1) melakuakan pembacaan pengukuran

percobaan/demonstrasi/praktikum. (2) mampu menyatakan pendapat pada saat pembelajaran/percobaan/demonstrasi/praktiku - (3) menyimak pada saat berlangsungnya proses belajar mengajar, (4) membuat laporan, (5) grafik/diagram, (7) menganalisis data percobaan/demonstrasi/praktikum.

Dari data tersebut dapat diimplikasikan bahwa pada kelas kontrol siswa aktif. Namun jika dibandingkan dengan kelas eksperimen yang diberi perlakuan pembelajaran berbasis lingkungan sekitar dilihat dari aktivitas siswa maka kelas eksperimen (VC) lebih aktif, yakni dapat dilihat dari perolehan skor rata penilaian antar teman 4,22 (SB) > penilaian antar teman kelas kontrol (VE) 3,87 (B).

Setelah pelaksanaan pembelajaran berbasis lingkungan selesai, siswa diberikan angket peserta didik. Angket peserta didik diberikan untuk mengetaui pendapat atau apa yang sudah dirasakan oleh siswa dengan pembelajaran berbasis lingkungan. Dari angket yang sudah dibagikan diperoleh sor rata-rata 3,45 dengan predikat baik. Dengan rincian dari 9 siswa perolehan skor rata-rata dalam predikat sangat baik dan 4 siswa dalam kategori baik, 1 siswa dalam kateori kurang baik dan 1 siswa dalam kateori tidak baik.

Angket Peserta didik ditinjau dari per bidang aspek dari12 aspek, dengan rincian 10 aspek skor rata-rata dalam predikat sangat baik dan 2 aspek skor rata-rata dalam predikat sangat baik dan 2 aspek . Pada saaat pelaksanaan pengisian angket hanya ada 13 orang siswa, dikarenakan pada saat itu banyak siswa yang tidak hadir.

Untuk menilai kinerja siswa pada saat pelaksanaan pembelajaran berbasis lingkungan sekitar pada pertemuan 1, maka dilakukan penilaian performance. Penilaian performance merupakan penilaian kinerja siswa pada saat pembelajaran dengan dihadapkan pada kondisi ril. Berdasarkan penilaian penilaian performance yang telah dilakukan diperoleh skor rata rata 3,36 dalam kategori baik. Dari 21 siswa terdapat 12 siswa dengan kriteria cukup baik dan 6 siswa dalam kategori baik. Dari 11 aspek, performance yang dinilai, siswa sudah dalam kateori sangat baik untuk aspek mengklasifikasikan, (6) melakukan eksperimen dan (9) menganalisis data. Siswa sudah dalam kateori baik untuk aspek (5) mengidentifikasi dan mengontrol variabel ( 10) mengomunikasikan dan menyimpulkan. Siswa sudah dalam kateori cukup baik untuk aspek (1) pengamatan saat eksperimen keterampilan mengobservasi dan aspek (7) mengukur dan menggunakan angka. Dan siswa dalam kateori tidak baik untuk 
aspek (3) Memprediksi (4) Menyusun hipotesis dan (8) Menginterpretasikan data. Untuk penilaian penilaian performance yang telah dilakukan pada pertemuan 2 diperoleh skor rata rata 3,48 dalam kategori baik. Dari 18 siswa, 8 siswa dalam kategori cukup baik dan 10 siswa dalam kateori baik. Dari 11 aspek, performance yang dinilai, siswa sudah dalam kateori sangat baik untuk (2) mengklasifikasikan. (6) mengidentifikasi dan mengontrol variabel. (9) menganalisis data, dan (11) menyimpulkan. Siswa sudah dalam kateori sangat baik pada aspek (4) menyusun hipotesis, (5) mengidentifikasi dan mengontrol variabel dan (7) mengukur dan menggunakan angka. Siswa dalam kateori tidak baik pada aspek (3) memprediksi dan (8) menginterpretasikan data.

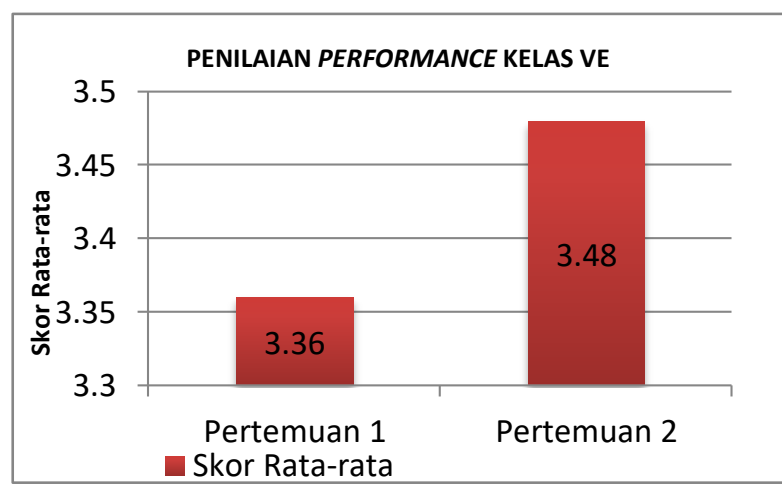

\section{Grafik 4. Penilaian Performance Kelas VE}

Pada pelaksanaan pembelajaran berbasis lingkungan pemaksimalkan pembelajaran IPA dengan pemanfaatan lingkungan sekitar dengan pembuatan instrumen pembelajaran yang terwarnai dengan authentic assessment. Pembelajaran dilaksankan dengan menerapkan authentic assessment dimana pembelajaran dan penilaian tidak terpisahkan dengan berbasis authentic assessment yang tentunya dengan memixkan dengan pembelajaran berbasis lingkungan sekitar.

Pengkonsep pembelajaran IPA yang bemakna dan berkualitas lewat pemanfaatan lingkungan sekitar penganalisaan kondisi yanga ada di sekolah, penganalisaan standar kompetensi dan kompetensi dasar, perancangan dan penjadwalan penelitian dari awal hingga akhir, pelaksanaan pembelajaran IPA dengan berbasis lingkungan sekitar, dan penilaian pembelajaran IPA dengan berbasis lingkungan sekitar.

Penginovasian pembelajaran IPA dengan pemanfaatan lingkungan sekitar yang dapat mengaktifkan siswa yakni dengan pembuatan instrumen yang kesemuanya berciri khas authentic assessment dengan memixkan variabel penelitian aktivitas siswa. Pada saat pembelajaran berlangsung dengan berbasiskan lingkungan sekitar yang bersifat authentic sampai tahap proses penilaian pun dialakukan dengan authentic assesssment, yakni siswa dihadapkan pada kondisi ril dalam hal ini terjun langsung pada lingkungan sekitar. Penginovasian pembelajaran IPA dengan pemanfaatan lingkungan sekitar yang dapat mengaktifkan siswa yakni berdsarkan pre test siswa yang sudah mencapai nilai KKM ( $\geq 70) 4$ orang $(21,05 \%)$, post test siswa yang sudah mencapai nilai KKM ( $\geq$ 70) 9 Orang (60 \%), angket yang sudah dibagikan diperoleh sor rata-rata 3,45 , penilaian performance yang telah dilakukan pada pertemuan 2 diperoleh skor rata rata 4,29 dalam kategori sangat baik, penilaian 
performance yang telah dilakukan diperoleh skor rata- rata 3,37 dalam kategori baik. Pembelajaran IPA dengan berbsis lingkungan sekitar selain meningkatkan keaktifan juga menumbuhkan kecintaan pada lingkungan, siswa juga benar-benar merasakan pembelajaran di dunia ril yang tidak terpaku hanya pada lingkup kelas duduk dan mendengarkan guru. Pengaplikasian teori yang didapatkan dapat diaplikasikan langsung dalam konteks ril. Hal tersebut tercermin dari penilaian diri yang diisi oleh siswa.

\section{SIMPULAN}

Pemaksimalkan pembelajaran IPA dengan pemanfaatan lingkungan sekitar pada saat pelaksaan pembelajaran dengan pembuatan instrumen pembelajaran yang terwarnai dengan authentic assessment. Pembelajaran dilaksankan dengan menerapkan authentic assessment dimana pembelajaran dan penilaian tidak terpisahkan dengan berbasis authentic assessment yang tentunya dengan memixkan dengan pembelajaran berbasis lingkungan sekitar.

Pengkonsep pembelajaran IPA yang bemakna dan berkualitas lewat pemanfaatan lingkungan sekitar Penganalisaan kondisi yanga ada di sekolah, penganalisaan standar kompetensi dan kompetensi dasar, perancangan dan penjadwalan penelitian dari awal hingga akhir, pelaksanaan pembelajaran IPA dengan berbasis lingkungan sekitar, dan penilaian pembelajaran IPA dengan berbasi lingkungan sekitar.

Penginovasian pembelajaran IPA dengan pemanfaatan lingkungan sekitar yang dapat mengaktifkan siswa yakni dengan pembuatan instrumen yang kesemuanya berciri khas authentic assessment dengan memixkan variabel penelitian aktivitas siswa. Pada saat pembelajaran berlangsung dengan berbasiskan lingkungan sekitar yang bersifat authentic sampai tahap proses penilaian pun dialakukan dengan authentic assesssment. Penginovasian pembelajaran IPA dengan pemanfaatan lingkungan sekitar yang dapat mengaktifkan siswa yakni berdsarkan pre test siswa yang sudah mencapai nilai KKM ( $\geq$ $70) 4$ orang $(21,05 \%)$, post test siswa yang sudah mencapai nilai KKM ( $\geq 70$ ) 9 Orang (60 \%), angket yang sudah dibagikan diperoleh sor rata-rata 3,45 , penilaian performance yang telah dilakukan pada pertemuan 2 diperoleh skor rata rata 4,29 dalam kategori sangat baik, penilaian performance yang telah dilakukan diperoleh skor rata- rata 3,37 dalam kategori baik.

\section{DAFTAR PUSTAKA}

Arifin, Johar. (2017). SPSS24 untuk Penelitian dan Skripsi. Jakarta: PT. Elex Media Komputindo.

.(2017). Ragam Model Penelitaian dan Pengolahannya dengan SPPS. Yogyakarta: Andi.

Hamalik, Oemar. (1995) Kurikulum dan Pembelajaran. Jakarta: Bumi Aksara.

Hamalik, Oemar. 2009. Proses Belajar Mengajar. Jakarta: Bumi Aksara. 
Latifah, Noor. 2008. Hakekat Aktivitas Siswa,

(Online)

(http://Latifah-

04wordpress.com, di akses 3

november 2011).

Rahmat.2000. Model Penelitian Komunikasi.

Bandung: Remaja Rosdakarya.

Sanjaya, Wina (2009) Kurikulum dan

Pembelajaran. Teori dan Praktek

Pengembangan Kurikulum Tingkat

Satuan Pendidikan (KTSP). Jakarta:

Kencana.

Sardiman. 2010. Interaksi dan Motivasi Belajar Mengajar. Jakarta: Rajawali Pers.

Sukardjo. (2012). Konsep dan Model Pembelajaran Sains, Hand Out. Daerah Istimewa Yogyakarta.

Trianto. 2013. Model Pembelajaran Terpadu. Jakarta: Bumi Aksara. 